\title{
Roma and Gypsies in the Mediterranean: Circulating Categories, Maintaining Boundaries
}

Roms et Tsiganes en Europe méditerranéenne : prégnance et circulation des catégories

Roma y gitanos en el Mediterráneo: distinciones étnicas, enraizamiento y circulaciones

\section{Milena Doytcheva}

\section{(2) OpenEdition}

\section{Journals}

Electronic version

URL: https://journals.openedition.org/remi/8478

DOI: 10.4000/remi.8478

ISSN: $1777-5418$

This article is a translation of:

Roms et Tsiganes en Europe méditerranéenne : prégnance et circulation des catégories - URL : https://journals.openedition.org/remi/7568 [fr]

\section{Other translation(s):}

The Arab Spring: A Revolution for Egyptian Emigration? - URL : https://journals.openedition.org/remi/ 8481 [en]

"The cinema needs the individual, and migrants need the cinema to re-emerge as an individual." Interview with Andrea Segre - URL : https://journals.openedition.org/remi/8595 [en]

Mapping the Migratory Movements - URL : https://journals.openedition.org/remi/8803 [en]

The measure of migratory flows between France and other countries; what if we also spoke of emigration? - URL : https://journals.openedition.org/remi/12090 [en]

Immigrant Youth in Canadian Postsecondary Education: Pathway Morphologies in the Province of Quebec - URL : https://journals.openedition.org/remi/12100 [en]

\section{Publisher}

Université de Poitiers

\section{Printed version}

Date of publication: 1 March 2016

ISBN: 979-10-90426-27-6

ISSN: 0765-0752

\section{Electronic reference}

Milena Doytcheva, "Roma and Gypsies in the Mediterranean: Circulating Categories, Maintaining Boundaries", Revue européenne des migrations internationales [Online], vol. 32 - $n^{\circ} 1$ | 2016, Online since 01 March 2018, connection on 14 April 2022. URL: http://journals.openedition.org/remi/8478 ; DOI: https://doi.org/10.4000/remi.8478 
This text was automatically generated on 14 April 2022.

(C) Université de Poitiers 


\title{
Roma and Gypsies in the Mediterranean: Circulating Categories, Maintaining Boundaries
}

\author{
Roms et Tsiganes en Europe méditerranéenne : prégnance et circulation des \\ catégories
}

Roma y gitanos en el Mediterráneo: distinciones étnicas, enraizamiento y circulaciones

Milena Doytcheva

1 Within the background of an important and long-standing issue for ethnic studies about the individual and more collective framings of identification, belonging, and mobilisation, the article aims to explore the situations of age-old integration and the more recent visibility, driven by European mobilities, of populations identified as Roma and Gypsies (Tsiganes) ${ }^{1}$. It proposes to pay attention to the way in which historical situations of minorisation have been reset in recent years by the spread of new intraEuropean migrations, thus favouring a particular path of analysis, which is the one of ethnic labels and distinctions underpinning the definition and politicisation of these issues. Drawing on the study of three main countries of immigration in Europe, namely Spain, France and Italy, we shall examine how the movements under way in the recent period from Eastern Europe have, to a greater or lesser extent, renewed old minority settings. What have been their consequences in terms of identification, and collective claims and actions? How do the ethnic distinctions at play represent, or not, relevant categories of knowledge and intervention to reflect on the dynamics of integration of those who experts identify as the "the largest European minority"?

The Mediterranean Basin offers, in this sense, a relevant entry point, as it seems to form a "nodal area" both in the historic processes of Romani dispersion and the recent waves of immigration (Bergeon, 2015). Building on a comparative analytical framework, drawing on research about Gitanos in Spain, Romanlar in Turkey, Roma in Bulgaria, among others, we tend to show that European policies are not without some influence 
on the processes of social, national and more local construction of Roma public identities, while the literature mainly insists on the idea of a "local prism" in the perception and formulation of a haunting "Gypsy problem" (Sigona, 2005) ${ }^{3}$. Siding with these rapid preliminary remarks, we argue the need to systematically test these questions through various public arenas and "scales of justice" (Fraser, 2008) - local, national, supranational and European - underscoring the logics of category and policy mobilities (McCann, 2011), as well as unveiling processes of boundary maintenance. Indeed, while the emergence of a supranational political space has, in recent times, fostered the possibility for claiming rights and equality (Balibar, 2011), it is undoubtedly far from exhausting the long-standing and deep-rooted system of persecution and prejudice, tied to Anti-Gypsyism, which these populations have been experiencing in a differentiated way through space and through time. Finally, rather than a continuity or a mere juxtaposition, we argue the conflicted integration of policy schemes and interventions, whereby the "protection of minorities" intersects, and sometimes blankets, age-old situations of exclusion and discrimination.

\section{The Public Figure of the Roma: A European Perspective}

3 Recently, these issues were first raised in the East, within the countries of Central and Eastern Europe, which, in the wake of several decades of Communism, had to reset a democratic rule of coexistence between various ethnic minorities. In this context, the concern was first formulated for the Muslim populations. Then, in the middle of the decade, it shifted towards the Roma (Ragaru, 2008; 2015), who endured growing victimisation and rampant social and economic marginalisation. The common and, in theory, generic identification of Roma prevailed rapidly to define them, against the traditional, local and more usual denominations (e.g. Tigani, Tsigani, Cingeneler, Zingari...). This renewal of identification partook also of a rationale of "destigmatisation" (Pierrot, 2011). In fact, while these latter designations are exonyms, the term Roma (Rrom in certain spellings and variants of Romani) is deemed, on the contrary, to form an endonym, and to be clearly part of an identity claim and mobilisation, or to have been so at least at the start.

\section{Salience of Culture and Pervasiveness of Race}

4 To shed light on these dynamics of Europeanisation and "transnationalisation", the use of ethnonyms and identificatory processes is indeed a heuristic opportunity. While, as demonstrated by Denys Cuche (2008), social categorisation is vital to the existence of any social group, categorising is not neutral. In everyday French, the term is implicitly pejorative, especially when used for vulnerable and deprived populations (Pierrot, 2011). Derived from kategorein, it means both "speak against, accuse, reproach" and "state, signify, affirm". By using the power of revelation exercised by objectification in discourse, "'ethnic' or 'regional' categories, like categories of kinship, institute a reality" (Bourdieu, 1980). This "reality" is however not given but historically constructed and situated in the societies that use and legitimate them (Desrosières, 1993; Martiniello and Simon, 2005). As part of the definition and social recognition of groups that could legitimately act in democratic life, and possibly claim specific rights, 
these processes are a strategic issue of power in post-migratory societies. It is the power to impose a vision and representation of the world that are perceived as legitimate, but also the power to re-signify assigned identities, a power that is often denied to minoritarians (Guillaumin, 1972).

In this essay, so as to refer to the study population, we follow the expression coined by the French scholar Jean-Pierre Liégeois (2009; see also Doytcheva, 2015), of "Roma and Gypsies" (Roms et Tsiganes). Although, from the author's viewpoint, these two terms are not synonyms, by borrowing multiple strategies of identification, we try, for instance, to underscore the fluidity and malleability of these collective identities. In addition, this allows the combination of a self- and a hetero-identification, given that many people today referred to as Roma identify themselves first and foremost as Gypsies, including in emigration societies. The latter form a traditional category, often considered as more socially meaningful than Roma, which may be perceived - especially in France - as a neologism. Thereby we move away from any attempt of an "objective" definition of these groups and collective "identities", emphasizing the way in which ethnic labels and distinctions are categories of ascription and identification by the actors themselves, primarily based on social relations, and used in order to organise interactions (Barth, 1969; see also Martiniello, 1995; Poutignat and Streiff-Fénart, $2008)^{4}$.

6 Institutionally, from the end of the 1960s, the Council of Europe was one of the first to address these issues. Amid a series of resolutions, recommendations and reports, its action could be characterised as global: the promotion of culture, the teaching of the Romani language and access to information and education occupy a prominent place (Liégeois, 2007). In the approach developed by the CoE, Gypsies are also a "true European minority" that greatly contribute to the cultural diversity of Europe (Recommendation 1203 of 1993). The aim of their identification and recognition - local versus transnational and European communities - has, in recent years, been at the centre of an important appraisal work. In 2003, following a dedicated seminar ${ }^{5}$, the Council committed to a "harmonisation of terminology": the term "gypsy" was officially banned in 2005, at the request of the community's organisations, who saw this term as an exogenous and paternalistic identification, laden with stereotypes. At the end of the decade, the term "Roma" prevailed as the generic designation and in theory common to all communities ${ }^{6}$. It should be noted that this work was followed by other European actors, in particular the European Commission and the European Union Agency for Fundamental Rights (FRA). In order to fight the effects of reification associated with single, univocal categorisation, alternative spelling forms have been used: Rromani (with a double $\mathrm{r}$ as in certain variants of the Romani language and in certain schools), Romany (another variant of Romani); or even the multiplication of identificatory strategies, more so in the academic field, which we also endorse here: "Roma/Gypsies", "Roma and Gypsies", "Roma and Sinti" in Italy.

But, while it undoubtedly opened new forums to claim rights and equality, the development of European and EU institutions may have produced "contradictory effects" on these issues. According to Etienne Balibar (2011), while, on the one hand, Europe granted Romani people a common identity, or rather a categorisation, this may have contributed on the other hand to a process of racialisation (cf. also infra), putting the Roma in the same category as "third-country nationals", in the general framework of an emerging "European apartheid", the dark side of the European citizenship. Also 
adding to such a misapprehension is the question of "origins", which is often raised about them, and significant of the clumsy will to valorise Roma - as "Indo-Europeans", who came from India, etc. - whereas the priority for those concerned is first of all to obtain the same national legitimacy as their fellow citizens, or in some ways the right to be natives (Pierrot, 2011).

In these analyses, several aspects characterise the current situation: one of them concerns the tendency of Europeans to project onto Roma their own racial prejudices vis-a-vis other nations. If the French press is eager to report on pogroms taking place in Italy or Hungary, or discrimination in Romania, it remains almost silent on the way in which local councils in France reject "nomads" from their territory, or the way in which the French border police expel Romanians and Bulgarians to maximise their official records, knowing full well that, as EU citizens, they will soon be returning (Balibar, 2011; Dalibert and Doytcheva, 2014). European nations, who officially have surmounted their age-old hostilities, are in fact still full of mutual resentment and distrust, that they tend to project onto "deviant" groups. The Roma, like a "nation in excess", are an ideal target for the crystallisation and shift of these intra-European xenophobic tendencies. Through their trajectories of mobility and deterritorialisation, they "incarnate the archetype of a stateless people, resisting the norms of cultural homogeneisation" (Balibar, 2011: 141). The task of their identification however should not be limited solely to the work of international bodies involved in "minority protection".

9 As shown in France by the work of Henriette Asseo (2007), as early as 1905, in "police conventions", an "international gypsy question" was raised, leading at the time to the implementation of discriminatory legislation in almost all European countries. Therefore this raises the question of differences and commonalities between the current situation of transnationalisation and other historical configurations ${ }^{7}$.

\section{Racism and Neoliberalism: The Roma Example}

10 Following the thesis of a recent book sought to explore the complex historical relationship between immigration, democracy and racism (Fitzgerald and Cook-Martín, 2014), the conventional claim according to which these two concepts are antithethical cannot explain why liberal democracies led the way in the adoption of racist immigration policy and were slower to repeal those racist laws. But while liberalism, authors argue, "has had a greater affinity with ethnic selectivity than with universalism", this link is not necessary, i.e. deterministic, but rather probabilistic. There is no "iron law" connecting them. Rather than positing a strong correlation, it would be thus more appropriate to study the way in which the age-old phenomenon of Anti-Gypsyism today resounds with the neoliberal rationale of capitalism.

In this sense, the trend of neoliberal urban governance, which excludes and sends the most vulnerable to its outskirts, is first invoked. When receiving various empirical tests (Günes, 2015; Sarcinelli, 2015), the hypothesis cannot admit an unequivocal validation, as it is true that examples of segregative and exclusionist urban treatment are so numerous and various in time and space, for current governance to be their sole explanatory factor. In a recent essay, by following the analyses of Michel Feher, Éric Fassin proposes another interpretation of the current activation of Anti-Gypsyism by neoliberal capitalism. According to him, if amid the political changes that intervened in 
2012 in France there was no change in the political handling of the "Roma issue", no more than in that of austerity policies, it is because both "are the flip side of a same neoliberal policy" that these governments from different political boards "are sharing" together (2014: 62).

By using Feher's words, Fassin dwells on "a neoliberal condition" whose nature is to give a value to everything, where everything is driven by an "aspiration to rise in value". But what happens in these conditions of life with no value, hardly even worth throwing away? The "Roma issue" would thus symbolise, on the basis of the minority exception, what could as well be the rule for the majority, that of a "throwaway economy" and a "policy of scrap". The author then operates a link with the Foucauldian concept of biopower: "Race, racism, is the condition for the acceptability of putting to death in a society of normalisation ${ }^{8}$ ". Racism introduces a caesura into the biological continuum addressed by biopower. It is the source of an original biopolitical regime invented by neoliberal governmentality in relation to the Roma: "Not letting them live, without necessarily making them die" (Fassin et al., 2014: 70). By taking pain as a political analyser, Lorenzo Alunni (2015) studies the current forms of this biopower exerted over migrants, through the medicalisation of campi romi and the mobilisation of humanitarian policies and emergency aid towards them. Not without paradox, in these examples, humanitarian morals contribute to a securitarian government (Ticktin, 2011), when "protecting the Roma" also allows to "protect society against the Roma". Whether in terms of health or "parenting", the copresence of suspicion and a compassionate relationship to these individuals constitutes a structuring and strongly racialising scheme (Sarcinelli, 2014; Alunni, 2015).

Finally, as shown by the examples above, the logics of Anti-Gypsyism can thus intersect those vowed to tackle it. However, in light of an historical and comparative perspective, we argue, its link to liberalism cannot be essentialised. Sometimes "totalitarian", sometimes "liberal", “democratic" or "post-communist", expressions of racism resound with more general schemes of perception and domination in society. As shown by Nadège Ragaru, based on a fine-grained analysis of policies established by emigration countries, rather than a contradiction or ideological opposition between different policy frameworks adopted over time, it is more so a process of sedimentation that can be observed in practice. At a time when (Western) European advisors were busy exporting "best practices", a more ambiguous configuration succeeded, in which the homogenisation of practice and knowledge had the downside of disseminating models "henceforth saturated with shared prejudices" (Ragaru, 2008, 2015).

\section{Transnational versus Local Minority?}

Within the neoliberal scenario, other hypotheses and more specifically French ones, underscore the role played in these processes by the European and international organisations: this is "the Roma issue's expert manufacture", a laboratory of neoliberal social policy, according to such analysis (Olivera, 2011: 115). By fabricating this new category of intervention, and by bringing it forward to the attention of public opinions and policymakers, these organisations may have, in fact, subsequently produced "the Roma problem" itself. They may have created, in this way, a "diversion" allowing them to delete from agenda social and economical difficulties, recurring crisis, and austerity policies. The fall of the Berlin Wall, in 1989, may have played on these issues "the same 
role" as the weakening of the Ottoman Empire during the 19th century, following an argument that resembles Hirschman's thesis of futility 9 .

But the explanation of racism and discrimination through the existence of an ethnoracial structure of differentiation is, we argue, no less problematic. Indeed, to what extent are these structures of differentiation the source of power relations and to what extent are they the result of it? As sociological theories on racism claim, "contrary to what we often believe, the idea of "race" is not what racism is logically rooted in, but on the contrary, what it produces." (De Rudder et al., 2000: 35 et sq.). Reaffirming this perspective allows us to take into account the salience of processes of identity and cultural ascription. As Anne Philips put it on another, nonetheless related subject, culturalisation of objects and practices "works" because it is familiar to the majority, and not because it is "exotic" or "foreign" to it. Prejudices diffuse more easily when they resound with deep-rooted imaginaries that are available in the collective representations, already gendered, class-oriented, etc. (Phillips, 2007).

In addition, approaches carried out by international organisations are not all equal or uniform. For the Council of Europe, which, as we have seen, has focused on the issue since the late 1960s, Gypsies form a "true European minority" that greatly contribute to the cultural diversity of Europe. The European Charter for Regional or Minority Languages (1992) and The Framework Convention for the Protection of National Minorities (1995) are as such two main instruments of its policy that are not specific to the Roma. On the contrary, it was much more recently that the EU addressed the question, through changing political framings, and, as shown by some pioneering research, a groping construction of "public Roma issues". But above all, these concerns were subjugated to what we called a "dual European strategy" (Doytcheva, 2011).

Indeed, while the ratification of international instruments by Central and Eastern European countries was required as a condition prior to the accession negotiations, the same objective received little support and eventually raised suspicion in the countries of immigration ${ }^{10}$. Where it has come to question "who produces the 'knowledge' about this object?" and "for what reason?" (Olivera, 2011). According to this analysis, the "rhetoric of 'Roma victimhood" is not something new. It emerged at the turn of the 1990s with the first talks with Central and Eastern European countries, candidates for accession. But "the epistemology of knowledge" produced in these conditions is criticised (Farget, 2011). Supposedly influenced by a solely "objectivist" approach in the definition of these groups, it would have led to the crystallisation of mainly victimised representations associated with them. It thus may have helped to develop an only "palliative citizenship" (Thomas, 2010: 183), i.e. organised by others for them and most often without them. In addition, it may have contributed to a tendency towards overhomogenisation of the diversity of local situations.

18 But, however diverse the nature and trajectories of local situations, as evidenced by the different contributions to this volume (Nedelcu et al., 2016), and beyond, by a growing amount of research in the field, the groups thus identified qua Roma have in common a long-standing situation of exclusion and discrimination, backed by the century-old system of persecution, tied to Anti-Gypsyism. The latter can be defined as a particular form of racism, characterised by the (very) long-term persistence of prejudice, its systematic nature, the fact that it is accepted by the large majority, accompanied by acts of violence, a dehumanisation of individuals, as well as institutional and systemic discrimination ${ }^{11}$. From this point of view, while the notions of "identity" or 
"community" have been rightfully subject of criticisms, that of minority, in a sociological and not a statistical sense, seems to conform quite particularly ${ }^{12}$.

Although the principles of claiming rights and equality have been at the heart of approaches promoted by both European and international agencies during the postwar period, they seem, for the time being insufficient to deeply impact more local political arenas, at least in the sense of reversing long-standing situations of exclusion and prejudice. The very use of the category Roma bears witness to this. Flagged in an autonomous manner as an emblem of these communities in the early 1970s, at the first "World Romani Congress" held in 1971 in London (which led to the formation of the International Romani Union some years later), it was clearly, even though discretely, part of a "destigmatisation" strategy. Borrowed from the Romani language, the word Rom, which means "man", allows the group to differentiate itself from others by identifying with "men par excellence". But, as noted by the linguist A. Pierrot, once the most generic term is "monopolised to speak of oneself", from a majoritarian point of view it can be perceived on the contrary as specific and become demeaning (Pierrot, 2011). An ideological reversal is thus taking place in practises and representations, whereby policies designed to include the Roma can even overlap with situations of direct discrimination, on the pretext of taking them into account. To paraphrase A. Philipps, what resembles a process of accommodating differences, becomes the imposition of sameness.

\section{National Diversity Models and Roma Migrations}

An examination of national policies and local situations provides an instant illustration. Indeed, while the idea of a "Roma identity" is frequently denounced as a recent political construction, or even as a "mirage" of the "politics of recognition", patterns of racialisation, for their part, resound with the representations and structures of domination that are deeply entrenched in the majority and national views. By racialisation we mean the process of essentialisation and naturalisation of socially produced differences, whether based on culture, religion, history or physical and phenotypic traits ${ }^{13}$. The rationale of racism being to introduce a determinism between these arbitrarily isolated and socially constructed traits and individual behaviour, the distinctive feature of the assigned characteristics will be that they are considered as a form of "essence", predicating the intrinsic difference of these populations. Culturalism merges with biologisation thereby creating a radical otherness.

21 In France, Henriette Asséo highlights "a historical marginality, consubstantial with Bohemians" (2007: 161), backed by overriding and discriminatory legislation which spread in the beginning of the 20th century, operating an "exotic contamination" from immigrants towards nationals. The French Republic exerted very little corrective power over this. Rather than fighting ancestral prejudice against Bohemians, the Republicans on the contrary institutionalised it through various measures intended first of all for "nomads", then more recently for "Travellers" (Gens du voyage). The administrative category of "travellers", which designates (without having a clear definition) populations subject to derogations from common law, was established by the law of 3 January 1969, replacing that of "nomads", which had been in use since the law of 16 July 1912. Constructed from the 19th century onwards by extension from a professional category, the one of "fairground artists", to incorporate the deemed Gypsy 
groups, Travellers forms an "ethno-professional category" but also "a legal discriminatory tool” (Blum Le Coat et al., 2004; Belqasmi, 2015).

In order to shed light on these forms of segregative integration, from a historical and comparative perspective, we focus here on the study of the three main countries of immigration, which, in recent times, have been France, Italy and Spain. Thus we aim to clarify the way in which the respective national settings, built in the long term, in relation to local communities, account for policies dealing with the recent migrations and mobilities. To what extent have these national framings influenced the acceptance of EU programmes and objectives? From a more sociological perspective, how have recent waves of immigration redefined the boundaries of a supposedly common ethnic identity, underpinning specific strategies of mobilisation?

The French, Spanish and Italian cases provide very rich heuristic opportunities to approach such questions. We can schematically typify them on the basis of three-fold distinction: The "politics of recognition" of the Gitano people in Spain, in which the "new Roma" are included. Spain has thus often been presented, although somewhat superficially, as a "model of integration" for Romani populations. Building on the negative aspects of prejudice and a common assignment to the strongly racialised category of "nomads", rather than a claim for recognition, another case for continuity is offered by Italy. Lastly, in between these two, as usual, the French situation is characterised by the theoretical refusal of public regulation on ethnicity: the latest research invites us no less to consider the ways in which current situations are intertwining with previous definitions of "tsiganité" (gypsyhood), but also and very often, as we shall see, of coloniality.

\section{The Spanish “Model of Integration”}

The Spanish situation, which is relatively less studied in France compared to that of Italy, nevertheless provides an opportunity for particularly rich and stimulating insights. Spain is in fact the country with the highest number of new Eastern European immigrants: ranging between $50,000^{14}$ and 170,000 people (whereas 20,000 is the figure often given for France and 30,000 is cited for Italy). Unlike the other two countries, Spain did not apply a transitional regime for the 2007-2014 period for new EU citizens. While this did not overcome numerous situations of administrative and social difficulty, the influence of this choice on public opinion and policy interventions remains to be assessed.

In addition to being a privileged destination for recent migrations, the country has a long-standing reputation as a "model of integration" of the Gitanos. In the context of significant regional autonomy, these issues indeed found local relays. Catalonia and the Basque Country for example, built on principles of recognition to assert their legislative power. In 2001, Catalonia officially recognised "the identity of the Gitano people and the value of its culture"15. As the choice of terms shows here (that of people, rather than population), the approach is explicitly "transnational" and minority-based, thus meeting the frameworks promoted by the European organisations: many regional plans for the inclusion of Gitano people from the second half of the 2000s integrated measures in favour of the "new Roma" (Magazzini and Piemontese, 2015). Another striking feature is that Spain seems to be the only country (of the three studied here) to have directed these immigrants towards the common law structures of social action, 
mostly municipal ones. In both France and Italy the trend is almost reversed, with a prominent part of ad hoc solutions and specific measures, the latter having been partly the reason for greater visibility and mediatisation.

Research studies also highlight the role played by actors from the community, including the NGOs Gitano and pro-Gitano. While initially these associations seemed to be relatively uninterested, they began to address the issue as it became politicised at national level, and as dedicated European funds were implemented. The targeting of Roma populations is therefore based essentially on association networks, as is also the case in a significant manner in France when minority populations other than Gypsies are concerned ${ }^{16}$. For the latter, however, as we shall see later, in both Italy and France, selection is taking place today in an institutional manner, through public policy interventions, carried out by ad hoc structures, coming under rationales overriding the common law.

But the Spanish framework that seems to a certain extent to have succeeded with the local populations is today showing its limits, when it concerns adapting it to "Roma from other countries", according to the official designation. Indeed, on the one hand, there is a lack of association networks and they are not powerful enough to bear the interests of groups other than the local historic communities. On the other hand, more and more social practitioners seem to question the adequacy between Gitanos and "new Roma" in terms of social work.

Last but not least, the allegiance to a common identity, which is claimed in theory, is weakened in fact by the lack of solidarity and real inter-community bonds. Maintaining boundaries prevails over circulating categories, highlighting in actual manner the historical dimension in the construction of each minority situation (Sayad, 1977): longstanding and local for some, more recent and rooted in migration for others. In Spain, but also in France and in other countries of immigration, while recent mobilities have reactivated the issue of an ethnic identity, this is not raised spontaneously in the terms of solidarity (Roman 2014, Magazzini and Piemontese, 2015). The NGOs Gitano and proGitano fear in particular that the work carried out on fighting stereotypes and prejudice over several decades will be degraded by parallels made with these gitanos rumanos. Especially as the representation of the one who estafa u obra con engañ $0^{17}$ is still today an everyday definition of the Gypsy.

\section{The "Gypsy Nomadism"}

Spain is nevertheless the country where social and political mediatisation of a persistent "Roma issue", and the policies of expulsion and rejection that accompany it, have been less salient, even though the number of immigrants is slightly higher than those recorded in the neighbouring countries. Contrary to a common assumption, international requirements and European standards are therefore not without impact, as seen in the Spanish example, on policies implemented at local and national levels. However, far from reflecting a linear transposition or, by contrast, a form of resistance to supranational regulations, the latter are the result of a conflicted integration of schemes of knowledge and intervention, some of them, for instance the local ones, rather reshaped than discredited by European integration (Ragaru, 2015).

This is also what we learn from the study of the Italian situation, where the dynamics of continuity between past and present situations are illustrated, on the flip side of 
stereotypes and racial prejudice, through the use of a strongly essentialised category of "nomads". Rooted in the racial theories of the 19th century, as well as in Fascist research, the latter involves the ideas of heredity of the asociality and racial inferiority of the Gypsies: heterogeneous populations that share the common denominator of being identified as such (Sarcinelli, 2014, 2015). In the aftermath of the Second World War, however, a movement of solidarity towards them also developed here, and initiatives of valorisation and social promotion emerged. From the 1980s onwards these paved the way for city policies that focused on implementing special facilities to welcome families. Yet, as shown by Sarcinelli, these different philosophies (stigmatisation versus promotion) in reality only had one single result: segregation and marginalisation through the creation of these specific facilities (uffici nomadi, aree di sosta per nomadi, campi nomadi). The heterogenous group of Roma and Sinti, both Italian and foreign, settled or travellers, refugees or migrants, were thus all tarred with the same brush, being "nomads", and thus subjected to processing in dedicated offices. Reception areas were progressively transformed (including by their inhabitants) to become permanent camps, even though recent studies tend to nuance this observation (Maestri, 2015; Vitale, 2009). Seemingly marked by the will to protect minorities, this period saw a reappearance of the rationale of "gypsy nomadism", which had been used in the early 20th century to justify exclusion. The multiform nature of the mobilities observed in the recent period however retrieves them from such a nomadism, making them, on the contrary, perfectly fit with contemporary transnational migrations, part of a Europeanisation "from below" (Diminescu et al., 2003; Bergeon, 2015).

31 After a period of latent problematisation, these recent developments in Italy have nevertheless allowed "the Roma issue" to come to the fore, in the political arena, public debate, and at university. Even though the European frameworks of "Roma inclusion" seem, at first sight, to be at odds with local policies of securitisation and abandonment of migrants, neither have they been without some influence. Changing labels - from "Nomads" to "Roma" - are one example. Differentialist treatment continues however, accompanied by more subtle and discreet forms of exclusion, but with just as destructive results. The category of "Roma" under these conditions remains in an ambivalence between "racialisation and categorisation by policy interventions" (Sarcinelli, 2015). Also raised over the long term, the "humanitarian rationale", corroborates this segregationist treatment, on the fringes of generalist health care and social security institutions (Fassin, 2010; Alunni, 2015). Here lays another mechanism of subordination and insidious racisation, at grips with the biopolitical dynamics of governmentality and "inclusion".

\section{A Republican Ethnicity}

Between the Italian situation and the Spanish one, French policies seem to occupy an intermediary and in some ways ambiguous position (Nacu, 2010), due among other things to the claimed principles of "colour-blindness" and a long-standing refusal of ethnicity. In fact, however, they seem very close to Italian policies, as attested by a growing amount of comparative research (Legros and Vitale, 2011), as by lexical and conceptual proximities. As a consequence, it is often this "unthought" racial dimension of the Republican model, in politics as in public policy that is tackled by research. 
the bureaucratised category of "Travellers" (Gens du voyage) and that today of "Roma migrants" provide another meaningful exploration target. Indeed, while Travellers have been subjected since the 1970 s to very carefully designed administrative "deethnicisation", migrants originating from the East have been simultaneously construed as a group and community, a process in which the ethno-cultural but also ethno-racial dimension held an important position. While the French government refuses to include French Gypsies and Travellers in its "National strategy for Roma integration", a strong parallelism is at work in practices: implicitly, as in the housing and support operations implemented locally; and sometimes explicitly, in words and in political interventions ${ }^{20}$. These involuntary associations or deliberate conflation (Cossée, 2011), clearly indicate an essentialist rationale of racial ascription within a Republican framework, which nevertheless greatly refuses the principle ${ }^{21}$. As Mohamed Belqasmi (2015) puts it: whether it concerns brandishing the "Gypsy threat" or trials of unmeltability, the representatives of public authorities exploit accusations of anti-Roma racism in order to better ignore the day-to-day discrimination which hard-up local communities of Gypsies (Travellers) experience routinely.

Means of exemption and exception that guide local policy interventions with the Roma are not in fact dissimilar to "the Gypsy policies", also backed by overriding and discriminatory regulations at the beginning of the 20th century, in the context of an intensified "State work" of national identification (Nacu, 2010; Belqasmi, 2014, 2015; Doytcheva, 2016).

These developments invite us to explore the way in which contemporary issues are, more particularly in France, but also in other countries in a different way, part of a historical continuum, that is segregative and differentialist, without always being extraneous to a certain "Republican tradition" (Bessone et al., 2014). In operations aimed to dismantle what are considered "illegal installations" - as in their undersides that make up inclusion villages - whose stories pepper the news columns, just as in operations of "slum clearance" in the early 1970s, the implementation of public housing intervention is much a pretext for culling populations, achieving the selection of a few families deemed "suitable for integration", but neglecting the vast majority of undesirables. While the "inclusion villages" (Bessone et al., 2014; Doytcheva, 2016) have become trendy in recent years in France as a "best practice" for Roma integration, it is never implemented for other groups or populations. These concerns, that are particularly salient regarding the "welcome" of Roma people, bear witness, we argue, to the fact that their future is hardly perceived today in France through a "minority option" (Balibar, 2011), but appears rather well-rooted in the continuum of a particular Republican knowledge: segregative, but no less assimilationist.

It is finally by observing "from below" the paths and trajectories of immigrants in this "area of mobility and turbulence" which is the Mediterranean, that it has become possible to reconstruct the complexity of a "geography of cosmopolitanism", allowing 
us to think out new forms of hospitality and cohabitation (Bergeon, 2015). Circular or more classic, highly intense, these migrations, according to Céline Bergeon, despite everything, highlight territorial fluidities in the European area that the Roma fully experience. Italy, France and Spain are, for them, privileged settlement destinations and spawn new relationships, both within the family unit and with the neighbouring societies where they experience the co-presence of other migrating communities. Acquiring evolving skills and developing new relations favour faster integration, the maintenance and amplification of migration networks.

\section{Conclusion}

In a recent reflection on the scales of justice which invites the reader to reimagine political space in a globalising world, Nancy Fraser (2008) points out misframing as a mechanism producing new forms of inequality and injustice, in relation to a lack of representation, understood as "the ability to frame problems within appropriate political arenas". The territorial principle of national sovereignty is stale and in a growing number of situations no longer makes it possible to satisfactorily define the subjects of (in)justice, whose structural causes should not be territorialised. The author consequently calls upon a post-territorial means of political differentiation. While the approach of this post-territorial differentiation is not entirely clear, she suggests at least the application of an "all-subjected principle" (2008): the common subjection to a given governance structure that can be widely understood as a state formation, but also any non-state and trans-state agency that sets the ground rules governing social interaction can serve as a basis for the constitution of subjects of justice, beyond geographic proximity ${ }^{22}$. What unites them is the common condition of being subject to the coercive power of new forms of governmentality, which determine their existential perspectives. Human rights activists, international feminists, critics of "structural adjustment" policies are figures of political mobilisation that embody this new and critical standard for assessing the (in)justice of frames.

In a similar manner, in the examples we have studied, while the diversity of local situations is broad, the importance and the systemic nature of Anti-Gypsy biases, stereotypes and prejudices begin to form the horizon of such a common concern. Exclusion and discrimination, rather than, or with, identity and community, make it possible to conceive a policy on minorities that is rooted not in cultural specificities but in the structural causes of marginalisation and social exclusion. From this standpoint, if "the Roma issue" when viewed from France seems to be a recent invention, it is also important not to forget its entrenchment in a system of an extreme and "deep-rooted" socio-spatial segregation.

The comparative analysis framework we favoured here, both from a geographic and a historical perspective, invites us particularly to engage with such kinds of issues. We also argue for the necessity of an epistemic and methodological "shift" in their address: from the study of specific groups, to a more broadly informed approach in the field of sociology of migration, ethnic relations, racism and discrimination. Also partaking in this shift is the systematic investigation of different political arenas and scales of intervention. Among these, as we have seen, categorical distinctions, policy models and schemes are circulating. But rather than a juxtaposition, it is a conflicted integration that characterises this circulation, both at the institutional level and at that of political 
terms. As a result, a process of boundary maintenance is still at work. While the idea of a "common cause" or concern has emerged at recent times in the transnational arena, among activists, deputies and experts (whose portraits are still to be drawn with accuracy), we need more data on the routine relationships being created on the basis of everyday social interaction between migrants and local populations, whether minorised or not, whether from immigrant descent or not. Our study aims to provide a step and also an invitation to these kinds of prospect.

\section{BIBLIOGRAPHY}

Alunni Lorenzo (2015) La douleur politique. Enjeux du corps malade dans les campi roms de Rome, Confluences Méditerranée, 93, pp. 103-113.

Asséo Henriette (2007) L'invention des «nomades » en Europe au XXe siècle et la nationalisation impossible des Tsiganes, in Gérard Noiriel Éd., L'Identification. Genèse d'un travail d'État, Paris, Belin, pp. 161-180.

Balibar Étienne (2011) Racisme et politique communautaire : les Roms, Lignes, 34, pp. 135-144.

Barth Fredrik (Ed.) (1969) Ethnic groups and boundaries: The social organization of cultural difference, Boston, Little and Brown, $153 \mathrm{p}$.

Belqasmi Mohamed (2015) Entre dissuasion, assistance et activisme : l'accueil ambivalent des migrants roms en France, Confluences Méditerranée, 93, pp. 127-141.

Belqasmi Mohamed (2014) La construction d'une « question tsigane » : entre catégorisations et mobilisations sociales, Migrations société, 152, pp. 49-56.

Bergeon Céline (2015) La Méditerranée comme carrefour des mobilités des migrants roms, Confluences Méditerranée, 93, pp. 39-50.

Bessone Magali, Doytcheva Milena, Duez Jean-Baptiste, Girard Charles and De Latour Sophie G. (2014) Integrating or segregating Roma migrants in France in the name of respect: A spatial analysis of the villages d'insertion, Journal of Urban Affairs, 36 (2), pp. 182-196.

Blum Le Coat Jean-Yves, Catarino Christine et Quiminal Catherine (2004) Les Gens du Voyage : errance et prégnance des catégories, in Anne Gotman Éd., Villes et Hospitalités : les municipalités et leurs étrangers, Paris, MSH, pp. 157-176.

Bourdieu Pierre (1980) L'identité et la représentation. Éléments pour une réflexion critique sur l'idée de région, ARSS, 35, pp. 63-72.

Conseil de l'Europe (2012) Glossaire terminologique raisonné du Conseil de l'Europe sur les questions roms [en ligne] consulté le 22/07/2016. URL : http://www.angvc.fr/pdf/pouvoirs\%20publics/ institutions\%20europeennes/COE-20120518-Glossaire-Roms.pdf

Cossée Claire (2011) Les-Roms-migrants-et-gens-du-voyage, Lignes, 35, pp. 167-179.

Cuche Denys (2008) Modes de catégorisation et classement socio-ethnique au Pérou, in Frank Alvarez-Pereyre Éd., Catégories et catégorisation : une perspective interdisciplinaire, Paris, SELAF, pp. 35-55. 
Dalibert Marion et Doytcheva Milena (2014) Migrants roms dans l'espace public : (in)visibilités contraintes, Migrations Société, 152, pp. 75-90.

De Rudder Véronique, Poiret Christian et Vourc'h François (2000) L'inégalité raciste : l'universalité républicaine à l'épreuve, Paris PUF, $224 \mathrm{p}$.

Desrosières Alain (1993) La politique des grands nombres. Histoire de la raison statistique, Paris, La Découverte, $462 \mathrm{p}$.

Diminescu Dana, Ohliger Rainer et Rey Violette (2003) Les circulations migratoires roumaines : une intégration européenne par le bas?, Cahiers de recherches de la MIRE, 15, pp. 61-69.

Doytcheva Milena (2016) Between infra-right and public hospitality: Ambiguity in local policies towards Roma migrant families in France, IJMBS, 2 (4), pp. 365-381.

Doytcheva Milena (2015) Roms et Tsiganes en Europe méditerranéenne : l'actualité d'une question, Confluences Méditerranée, 93, pp. 9-25.

Doytcheva Milena (2011) Le Multiculturalisme, Paris, La Découverte, 128 p.

Farget Doris (2011) Étude du discours des juges et experts du Conseil de l'Europe sur l'identité Rom, La « question Rom » en Europe aujourd'hui, Tours, 24-25 mars.

Fassin Didier (2010) La raison humanitaire : une histoire morale du temps présent, Paris, GallimardSeuil, 368 p.

Fassin Éric, Fouteau Carine, Guichard Serge et Windels Anne (2014) Roms \& riverains : une politique municipale de la race, Paris, La Fabrique, $240 \mathrm{p}$.

Fitzgerald David S. and Cook-Martin David (2014) Culling the Masses. The Democratic Origins of Racist Immigration Policy in the Americas, Harvard, Harvard University Press, 512 p.

Fraser Nancy (2008) Scales of justice: Reimagining political space in a globalizing world, Cambridge, Polity Press, $224 \mathrm{p}$.

Guillaumin Colette (1972) L'idéologie raciste. Genèse et langage actuel, Paris, La Haye, Mouton, 378 p.

Günes Burcu Ö. (2015) À l'épreuve de la gentrification et de la transformation urbaine, Confluences Méditerranée, 93, pp. 81-90.

Hirschman Alfred O. (1991) The Rhetoric of Reaction: Perversity, Futility, Jeopardy, Harvard, Harvard University Press, 224 p.

Legros Olivier et Vitale Tommaso (Éds.) (2011) Roms migrants en ville, pratiques et politiques en Italie et en France, Géocarrefour, 86/1, [en ligne]. URL : https://geocarrefour.revues.org/8210.

Liégeois Jean-Pierre (2009) Roms et Tsiganes, Paris, La Découverte, 128 p.

Liégeois Jean-Pierre (2007) Roms en Europe, Strasbourg, Éditions du Conseil de l'Europe, 310 p.

Maestri Gaja (2015) The residential segregation of the Roma in Rome: Explaining the persistence of the Roma camps through comparison, Working paper, SemDoc CEE, Paris, Sciences Po, 16 July.

Magazzini Tina et Piemontese Stefano (2015) Modèles de gestion de la diversité en Europe et migrations roms : le cas espagnol, Confluences Méditerranée, 93, pp. 51-62.

Martiniello Marco (1995) L'ethnicité dans les sciences sociales contemporaines, Paris, PUF, 128 p.

Martiniello Marco et Simon Patrick (2005) Les enjeux de la catégorisation, Revue Européenne des Migrations Internationales, 21 (2), pp. 2-11. 
Ministerio de Sanidad Servicios Sociales e Igualdad (MSSSI) (2012) Estrategia nacional para la inclusión social de la población gitana en España 2012-2020, Madrid, MSSSI, 70 p.

Nacu Alexandra (2010) Les Roms migrants en région parisienne : les dispositifs d'une marginalisation, Revue Européenne des Migrations Internationales, 26 (1), pp. 141-160.

Nedelcu Mihaela, Ciobanu Ruxandra Oana et De Gourcy Constance (Éds.) (2016) Les migrations des Roms roumains en Europe, Revue Européenne des Migrations Internationales, 32 (1), pp. 7-182.

Olivera Martin (2011) La fabrique experte de la « question rom » : multiculturalisme et néolibéralisme imbriqués, Lignes, 34, pp. 104-118.

Phillips Anne (2007) Multiculturalism without culture, Princeton, PUP, 216 p.

Pierrot Alain (2011) Mythe nomade et logique migratoire, Lignes, 34, pp. 52-78.

Poutignat Philippe et Streiff-Fenart Jocelyne (2008) Théories de l'ethnicité, Paris, PUF, 304 p.

Ragaru Nadège (2015) Les productions internationales et locales des frontières ethnoculturelles : les Roms de Bulgarie saisis par les institutions, Confluences Méditerranée, 93, pp. 27-37.

Ragaru Nadège (2008) ONG et enjeux minoritaires en Bulgarie : au-delà de l'« importation/ exportation » des modèles internationaux, Critique internationale, 40 (3), pp. 27-50.

Roman Raluca (2014) Trans-National Migration and the Issue of "Ethnic" Solidarity: Finnish Roma Elite and Eastern European Roma Migrants in Finland, Ethnicities, 14 (6), pp. 793-810.

Sarcinelli Alice Sophie (2015) La question rom en Italie, entre logiques sécuritaires et logiques humanitaires, Confluences Méditerranée, 93, pp. 91-102.

Sarcinelli Alice Sophie (2014) Protéger, éduquer, exclure. Anthropologie de l'enfance et de la parentalité roms en Italie, Thèse en sociologie, Paris, EHESS.

Sayad Abdelmalek (1977) Les trois « âges » de l'émigration algérienne en France, ARSS, 15 (1), pp. 59-79.

Sigona Nando (2005) Locating “The Gypsy Problem”. The Roma in Italy: Stereotyping, Labelling and "Nomad Camps", Journal of Ethnic and Migration Studies, 31 (4), pp. 741-756.

Sigona Nando and Trehan Nidhi (Eds.) (2009) Romani Politics in Contemporary Europe. Poverty, Ethnic Mobilization, and the Neoliberal Order, Palgrave, MacMillan, 309 p.

Simon Pierre-Jean (2006) Pour une sociologie des relations interethniques et des minorités, Rennes, PUR, $347 \mathrm{p}$.

Thomas Hélène (2010) Les vulnérables : la démocratie contre les pauvres, Bellecombe-en-Bauge, Éditions du Croquant, $254 \mathrm{p}$.

Ticktin Miriam (2011) Casualties of care: Immigration and the politics of humanitarianism in France, Berkeley, University of California Press, $312 \mathrm{p}$.

Vitale Tommaso (Ed.) (2009) Politiche possibili. Abitare le città con i rom ei sinti, Roma, Carocci, 300 p.

\section{NOTES}

1. We follow here the expression coined by French scholar Jean-Pierre Liégeois (2009) in his classical essay. The use of italics is meant to emphasize the subjectivist and relational dimension of labels and ethnic distinctions, endorsed by actors in situation in order to categorize 
themselves and others for purposes of interaction (Barth, 1969). Whereby ethnic groups are primarily categories of ascription and identification, based on social relations. See also infra.

2. Ce texte est une traduction de la note de synthèse parue dans le vol. $32 \mathrm{n}^{\circ} 1$ (2016) de la REMI. Il a été traduit par Vicki Mcnulty de Trad2English, avec le soutien du CeRIES Université de Lille SHS.

3. We draw here on the results under development of the research project "Migrants roms dans l'espace public: (in)visibilités contraintes, mobilisations, habitat" (Ville de Paris, program « Paris $2030 "$, and Laboratoire d'excellence TEPSIS- EHESS, ANR-11-LABX-0067, 2013-2016). Through multiple field studies focused on processes of politicisation (media coverage, collective action, local policies of 'inclusion'), the project aims to explore in a cross-scalar and multi-situated approach the differentiated strategies of integration developed towards these immigrants by a plurality of actors (NGOs, elected officials, social workers, urban policy developers, international experts). Building on a comparative analytical framework, it points out some tensions between processes of 'transnationalisation' and rooted national and local configurations. See also for preliminary results Doytcheva $(2015 ; 2016)$.

4. We thus adopt a subjectivist and constructionist approach of ethnic distinctions, making emphasis on ascription as the critical feature of ethnic group. As Barth puts it, "the boundaries of the pariah group are most strongly maintained by the excluding host population" (Barth, 1969).

5. "The cultural identities of Roma, Gypsies, Travellers and related groups in Europe", CoE, 2003.

6. According to the definition by the Council: "The term 'Roma' refers to Roma, Sinti, Kale and related groups in Europe, including Travellers and the Eastern groups (Dom and Lom), and covers the wide diversity of the groups concerned, including persons who identify themselves as Gypsies." cf. CoE, Glossaire terminologique, May 2012, https://rm.coe.int/1680088eaa

7. Beyond and beneath, one could say, the posited distinction between segregation, exclusion versus nowadays integration, assumed however to produce similar effects.

8. Foucault Michel, «Il faut défendre la société ». Cours au Collège de France 1976, cited by Fassin (2014: 68).

9. According to the French aphorism recalled by Hirschman (1991) to sum up the futility thesis: "The more things change, the more they stay the same" (Plus ça change, plus c'est la même chose... ". Hirschman's futility thesis thus stipulates that some problems are so large and intractable that any efforts to address them are simply futile. As put by Olivera: "There is no point 'fighting against discrimination' or invoking 'inclusion', when it is the system itself as it functions that marginalizes the weakest ...”. It is not the Roma that need a voluntary and coordinated policy, because "a good part of these communities, both in the West and in the East, are very well integrated into local societies ... and do not ask but to lead their lives as they want, without reified categorizations coming from outside" (2011: 116).

10. Typically France, but also Italy or Netherlands, among others.

11. http://www.ergonetwork.org/antigypsyism.htm

12. I.e., which "is included in the processes of social classifications, differentiation and hierarchisation, within an unequal distribution of material and symbolic goods" (Simon, 2006: 152).

13. For further definition see, for example, De Rudder et al. (2000: 32 et sq.).

14. According to a low estimate by: Estrategia nacional para la inclusión social de la población gitana en España 2012-2020, Ministerio de Sanidad Servicios Sociales e Igualdad (MSSSI), 2012, p. 12.

15. Resolution 1046/VI by the Parliament of Catalonia "Sobre el reconeixement de la identitat del poble gitano i del valor de la seva Cultura", 21.11.2001 and Butlletí Oficial, No 240.

16. On these questions, we refer in particular to our work on French urban policies, that it would be too long to develop here (Doytcheva, 2007). 
17. Literally who "Scams or deceives", a Gitano definition still in use in the Royal Academy dictionary.

18. Following Wayne Brekhus, "the marked represents extremes that stand out as either remarkably 'above' or remarkably 'below' the norm. The unmarked represents a vast expanse of social reality that is passively defined as unremarkable, socially generic" (1998: 35).

19. As in the statement "they do not want to integrate" released by M. Valls, then Minister of the Interior, in the fall of 2013, arguing that Roma have 'a specific way of life' which 'confronts' French social norms. Interview at France Inter, the 24th of September 2013 (Dalibert \& Doytcheva, 2014).

20. As in the inter-ministerial meeting that followed President Sarkozy's discourse in Grenoble (July 2010), acting the government will to get rid of "the problems caused by the behaviour of some Roma and Travellers." (Doytcheva, 2016)

21. Travellers and Roma were included together in the first version of the "National Strategy for Roma Integration', produced by the write-wing government of François Fillon in 2011 at the request of the European Commission. In 2013, a revision is planned by Jean-Marc Ayrault, the new left Prime Minister, but does not really take place. It is hard to know today whether the 2011 text is still in force, while the socialist government expressed the willingness not to treat in one and same document 'Roma' and 'Travellers'.

22. The most obvious examples, Fraser argues, are the agencies that set the ground rules of global economy, but many other examples can also be cited, including agencies governing environmental regulation, security, policing, health, etc.

\section{ABSTRACTS}

The article is based on results under development of the research project "Roma Migrants in the Public Arena" (LabEx TEPSIS, Ville de Paris). Drawing on various fieldworks focused on politicization processes (media coverage, collective action, local policies of "inclusion"), it examines in a cross-scalar approach the differentiated integration strategies developed towards these immigrants by a plurality of actors. Through a critical review of the comparative results issued from the fresh release of Confluences Mediterranée journal, we point out some tensions between processes of "transnationalization" and rooted national and local configurations. We thus favour a particular research-path that focuses on entrenchment and mobilities of categorical ethnic ascriptions and identifications.

L'article s'appuie sur les résultats en cours d'élaboration du projet de recherche « Migrants roms dans l'espace public» (LabEx TEPSIS, Ville de Paris). À travers différentes enquêtes sur les processus de politisation (médiatisation, action collective, politiques locales d'«insertion»), il propose d'examiner les stratégies différenciées d'intégration développées à l'égard de ces migrants par une pluralité d'acteurs. Faisant retour sur les résultats comparatifs du dossier récent que la revue Confluences Méditerranée consacre à la question, nous analysons en situation les tensions entre une logique de "transnationalisation » de la problématique et l'enracinement des configurations nationales et locales concrètes. Une piste est en ce sens privilégiée qui est celle des catégories cognitives et d'action qui président à la définition de ces enjeux et objets d'intervention. 
El artículo se basa en los resultados en progreso del proyecto «Migrantes romaníes en el espacio público» (LabEx TEPSIS, Ville de Paris). A través de varias encuestas sobre los procesos de politización (mediatización, acción colectiva, políticas locales de «inclusión»), se propone examinar las estrategias de integración diferenciadas desarrolladas con respecto a estos migrantes. Haciendo una revisión crítica de los resultados comparativos del volumen que la revista Confluences Méditerranée ha dedicado a la cuestión, analizamos en particular la tensión entre un proceso de «transnacionalización» del problema y el enraizamiento de las configuraciones nacionales y locales concretas. Privilegiamos de tal modo una pista de investigación que es la de los modos de categorización que gobiernan la definición de estos sujetos y temas de acción.

\section{INDEX}

Palabras claves: roma, gitanos, integración europea, ciudadanía, migración, movilidad, política pública, categorización etnorracial, racialización, transnacionalismo

Keywords: Roma, Gypsies, European integration, European citizenship, migration, mobilities, public policy, ethnoracial categorisation, racialisation, transnationalism

Mots-clés: Roms, Tsiganes, intégration européenne, citoyenneté, migration, mobilité, politique publique, catégorisation ethnoraciale, racialisation, transnationalisme

\section{AUTHOR}

\section{MILENA DOYTCHEVA}

Associated professor of sociology, at Lille 3 University, CeRIES (EA 3589), Domaine universitaire du Pont de Bois, BP 60149, F- 59653 Villeneuve d'Ascq cedex; doytcheva.milena@gmail.com 